\title{
Developing a Web Enabled Gaming Approach to Mediate Performance Skills in Interorganisational Learning and Collaboration to Engineers
}

\author{
Klaus D. Thoben and Max Schwesig \\ Bremen Institute for Industrial Technology and Applied Worksciences, Hochschulring 20, D- \\ 28359 Bremen, Germany. \\ Email:Thoben@biba.uni-bremen.de
}

Abstract: $\quad$ As a consequence of dynamic markets - supported by developments such as globalisation and the current 'explosion of knowledge' - organisational capacity for learning is being identified as one of the key abilities for organisations to survive. As products are getting more complex, it often requires various enterprises with certain key competencies to produce a product in collaboration. Thus, especially interorganisational learning gains importance. Because of the high knowledge intensity within the actual product development and the production, particularly engineers are obliged to constantly acquire, share and transform knowledge into new products. Having examined an existing simulation game for Concurrent Engineering - COSIGA, which serves as a basis for further developments, we have identified key elements that are used to simulate organisational / interorganisational learning. By integrating these elements in COSIGA, we have developed a two level web based group simulation game aiming to mediate performance skills in the domain of organisational and interorganisational learning to engineers.

Key words: Simulation gaming, Organisational learning, Interorganisational learning, Company collaboration 


\section{PROBLEM}

As a consequence of dynamic markets - supported by developments such as globalisation and the current 'explosion of knowledge' - organisational capacity for learning is being identified as one of the key abilities for organisations to survive. As products are getting more complex, it often requires various enterprises with certain key competencies to produce a product in collaboration. Thus, especially interorganisational learning gains importance. Because of the high knowledge intensity within the actual product development and the production, engineers are obliged to constantly acquire, share and transform knowledge into new products. As a consequence of the stated developments, the way of working and the educational requirements that engineers have to face have changed as well. Performance skills about organisational and interorganisational learning and trust building competence are becoming vital. As shown, engineers need to know about organisational and interorganisational learning and how to apply this knowledge and the related skills in a working situation. Appropriate tools to mediate such skills are simulation games.

\section{STATE OF THE ART AND RESEARCH APPROACH}

According to RIEDEL, PAWAR, BARSON (2001), a simulation is based on a model representing a real life system to be learned. Simulations provide the opportunity to train and practice skills and knowledge without the risks involved with real life situations.

\subsection{Existing Simulation Games}

Existing games in the field of organisational learning and the closely related knowledge management like "KM QUEST" (SHOSTAK et al. 2002) or "ESCIO" (ADELSBERG et al. 2002), focus certain aspects of knowledge handling and knowledge sharing. Existing simulation games in the field of product development like "COSIGA" (PAWER et al. 1995), "City Car Simulation" (GOFFIN, MITCHELL 2002) and "GLOTRAIN" (WINDHOFF 2001) concentrate on the mediation of certain approaches or emphasize on important success factors in product development or even distributed production. As we were involved in the development of the COSIGA simulation game, which will serve as a basis for further developments, this gaming approach is examined in the following section in greater detail. 


\section{$2.2 \quad$ The COSIGA game}

The COSIGA simulation game focuses on the mediation of concurrent engineering (CE) principles and practices and enabled us to gain valuable experience about the simulation of $\mathrm{CE}$ and product design and in a gaming environment. Being played by five individuals in the same room (co-located) or in a distributed group (virtual) and using the Internet and telecommunications, the game aims to realistically simulate the collaborative and co-operative process of new product development inherent in a concurrent engineering approach. The players interact in a product development scenario where they have to specify, design and produce a simple truck for a specific market. The five players represent the typical roles of a product development process: Project manager, Marketing manager, Designer, Production manager and the Purchasing manager. The learning goal of COSIGA is to show players 'how to' communicate, co-operate and work collaboratively to achieve a common goal (PAWAR et al. 1995). COSIGA primarily deals with concurrent engineering and communication, but it does not consider interorganisational collaboration and learning as one essential part of today's manufacturing. As shown, performance skills about organisational and interorganisational learning and trust building competence are becoming vital. Thus, the new game emphasizes the active experience and reflection of key processes and challenges of organizational/ interorganisational learning.

\section{ENHANCING COSIGA}

After having regarded the COSIGA simulation game, which serves as a basis for further developments, we now identify key elements that are used to simulate organisational / interorganisational learning. By integrating these elements in COSIGA, we have developed a web based group simulation game to mediate performance skills in the domain of organisational and interorganisational learning to engineers. This research approach is illustrated in Figure 1.

\subsection{Identifying Processes and Challenges within Organizational Learning}

We interpret organisational learning from a multi level perspective, comprising of the individual, group, organizational and inter-organizational level (NONAKA 1994), since the point of view enables us to regard the main levels of action within an enterprise. According to this perspective, our working 
definition of individual level learning focuses on individual knowledge acquisition and is linked to the approach of self directed learning.

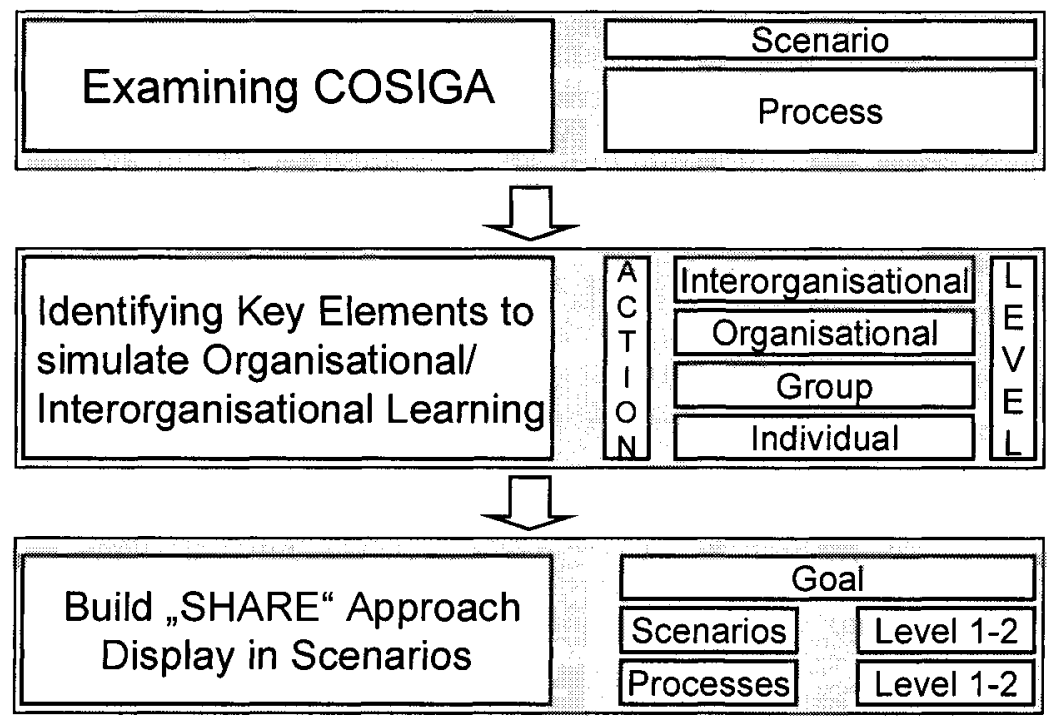

Figure 1. Research approach

(Source: THOBEN, SCHWESIG 2003, p. 256)

In the sense of group level learning, we follow MULHOLLAND et al. (2000) who defines group level learning as domain construction within communities of practice learning. By sharing vocabularies and practices, group communication and coordination during complex tasks is improved.

As MULHOLLAND et al. (2000) and SUMNER et al. (1999), we interpret organisation level learning as perspective taking. As organisations are typically composed of multiple interacting communities, each with highly specialized knowledge, skills and technologies, knowledge intensive firms require these diverse communities to bridge their difference to create a new shared perspective. By doing that communities recognize, use and evaluate the perspective of other groups. As a consequence of that, they view and evaluate themselves from another perspective in order to then create a shared cross community perspective. They are enabled to question work routines in order to reshape and thus improve their efficiency. Especially group level learning and organisational level learning are affected by "people barriers" like proprietary thinking, scepticism towards the sharing of knowledge and various fears (BARSON et al. 2000).

Interorganisational learning can happen in two ways: either through the transfer of existing knowledge from one organization to another, or through the creation of new knowledge (LARSSON et al. 1998). As the learning 
input comes from other organisations or joint interorganisational efforts, the intraorganisational learning activities continue to process knowledge as described above. In contrast to organisational learning, the participating organisations have to overcome certain organisational boundaries, like space, time, diversity, structure and distribution of knowledge and results (BOSCH-SIJTSEMA 2001). This makes interorganisational learning much more complex and causes much more effort. The interdependencies between the different learning levels are illustrated in Figure 2.

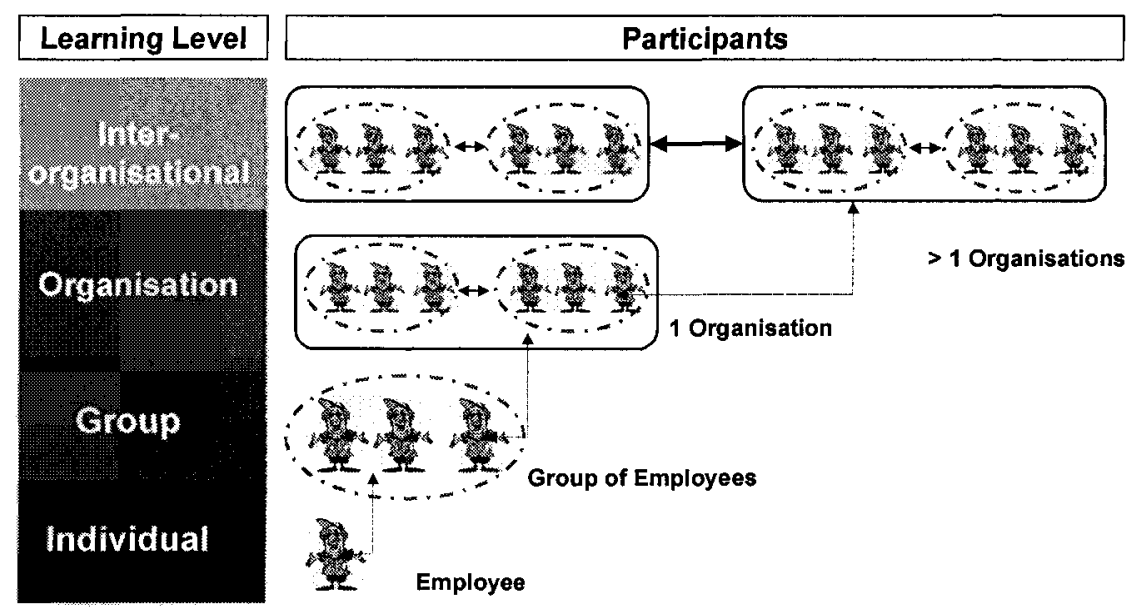

Figure 2. Interdependencies between the different levels of organisational learning

\subsection{The Game Scenarios}

As in COSIGA, the key process of the game is the joint experiencing of the development of a product in a virtual engineering working environment. In the first level, the players act as employees of an organisation that covers the basic economical functions: Design, procurement and sales/ services. Each department is made up by the particular department head and two employees. Since the game emphasizes the simulation of operational management processes within a company, the strategic position of the CEO cannot be played. As essential product of the modern watercraft industry and the "fun society", the Jetski was chosen as the central product of the first scenario in order to increase player's motivation, which indirectly improves the overall learning outcome. As initial evaluation and validation of the four step COSIGA product development process with target users have been very encouraging (RIEDEL, PAWAR, BARSON 2001), it will be adapted in the new game. 
Thus, the players have to specify, design and produce a Jetski in one company. Each department is responsible for the successful completion of at least one sequential step within this product development process. Figure 3 illustrates the whole structure and the processes of level 1 .

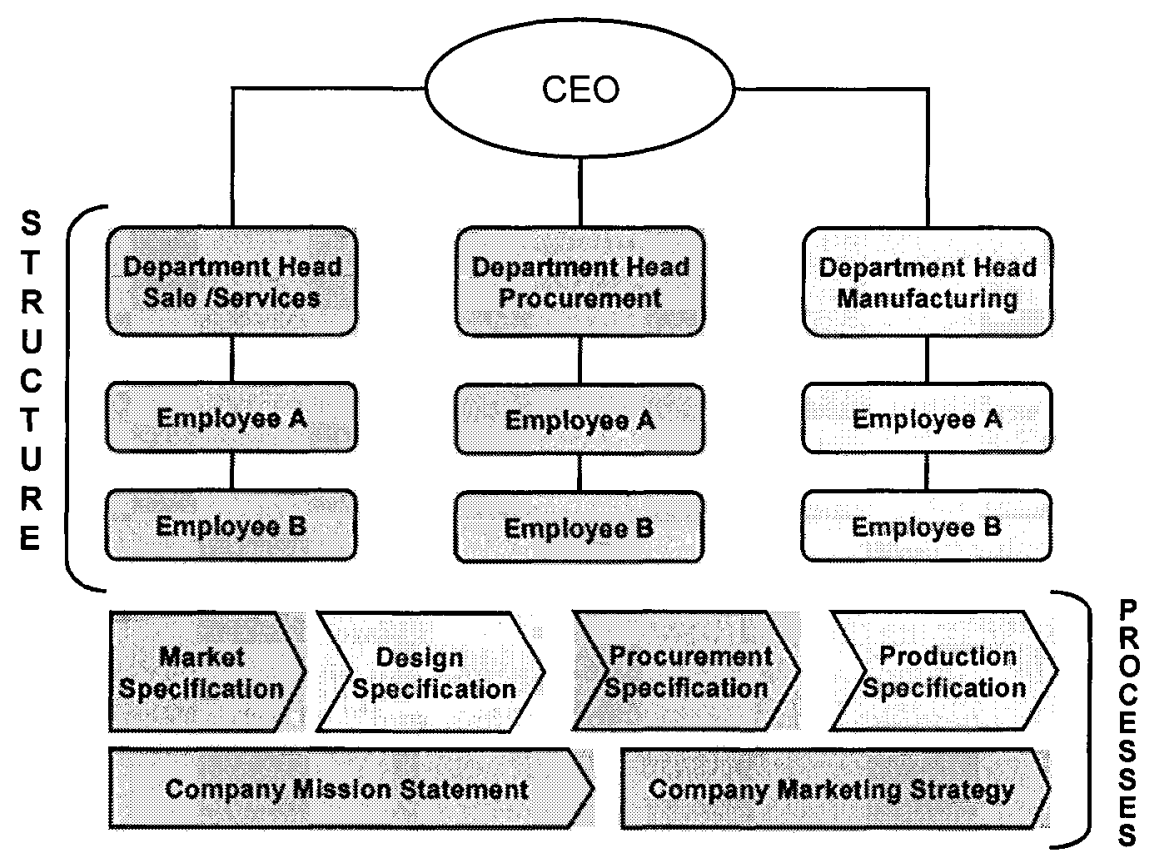

Figure 3. Game structure and processes of level 1

As the simulation of the realistic complexity within product development in a game would overextend the players, the following three-step process ha been developed. It consist out of three sub steps: First, basic information is provided to the players. By choosing between three different options, each having different durations and costs, the information is converted / enriched and then acts as basic information for the next step within the product development process. This process is applied throughout the game and can be illustrated by regarding the completion of the market specification: At the beginning of the game, basic market information is provided to the players. After having inserted it in a special template, the players can choose between either spying competitors, employing consultants, or buying a market study. After the players have chosen an option, new information in generated, which acts as input for the design specification. 
As a sequential product development process does not involve the whole company, idle departments are given specific tasks, which they have to solve in teamwork to simulate group level learning. The players thereby have to structure their efforts to solve the tasks and present their outcome in front of the whole company. Particular specific knowledge has to be retrieved from the internet. Among those tasks is e.g. the development of a company mission statement to enforce the shared company culture. In order to simulate organisational level learning realistically, information about the particular costs and durations of these options is distributed unequally among the departments, the players have to cooperate and to communicate to get this essential information to be successful. Following their role descriptions, some players act non collaborative to illustrate "people barriers". Together, the players experience the destructive effect of such behaviour. The forced communication between the departments supports the process of organisational level learning, as the members of the different departments have to look into the perspective of other players/groups in order negotiate successfully to get information. In order to improve the personal relations to others, the players can choose between various trust building measures (f.e."go dining" "schedule real world physical meeting" etc.). Table 1 summarizes the game characteristics within level 1.

Table I. Game characteristics within level 1

\begin{tabular}{|l|l|l|}
\hline \multicolumn{1}{|c|}{$\begin{array}{c}\text { Game Character- } \\
\text { istics }\end{array}$} & \multicolumn{1}{c|}{ Intended Effect } & $\begin{array}{l}\text { Simulated Process I } \\
\text { Challenge }\end{array}$ \\
\hline $\begin{array}{l}\text { Unequally distributed } \\
\text { information }\end{array}$ & $\begin{array}{l}\text { - Increased interdepart- } \\
\text { mental communication } \\
\text { to practice knowledge } \\
\text { exchange, cooperation }\end{array}$ & $\begin{array}{l}\text { Organisational level } \\
\text { learning/Perspective } \\
\text { Taking }\end{array}$ \\
\hline $\begin{array}{l}\text { Extra task for idle } \\
\text { departments }\end{array}$ & $\begin{array}{l}\text { Increased intradepart- } \\
\text { mental communication } \\
\text { to practice knowledge } \\
\text { exchange, cooperation }\end{array}$ & Group level learning \\
\hline Non collaborative \\
roles & $\begin{array}{l}\text { Experience destructive } \\
\text { effect of proprietary } \\
\text { thinking, } \\
\text { - Experiencing of the } \\
\text { value of trust } \\
\text { - Start loosing scepticism } \\
\text { towards knowledge } \\
\text { sharing }\end{array}$ & \\
\hline
\end{tabular}

Within the second level, the players deepen the acquired knowledge and skills in the interorganisational production of an extended product: a cell phone enriched by certain services. A cell phone was chosen as the product 
because of its common use in everyday life and its eligibility to present an extended product. Within the game, the players are acting as employees of three companies, that together form a consortium. This consortium consists of two manufacturing companies and one service providing company, which acts as the consortial leader. Each player is heading a department in one of the companies.

Again, the players have to complete particular specifications to then finally produce the cell phone and conceptualise services. To enable this interorganisational effort, the players first have to negotiate their collaboration contract in order to then specify, design and produce the cell phone. While the simulated service company takes consortial leadership and conceptualises services, the two simulated manufacturing companies develop, produce and assemble generic cell phone parts. Each company has the responsibility to complete a consortia wide part of the product development process. While the service company manages the consortial contract agreement and the market specification, one of the manufacturing companies arranges the procurement process; the other is responsible for the final assembly of produced generic cell phone parts. Figure 4 illustrates the structure and the processes within level 2.

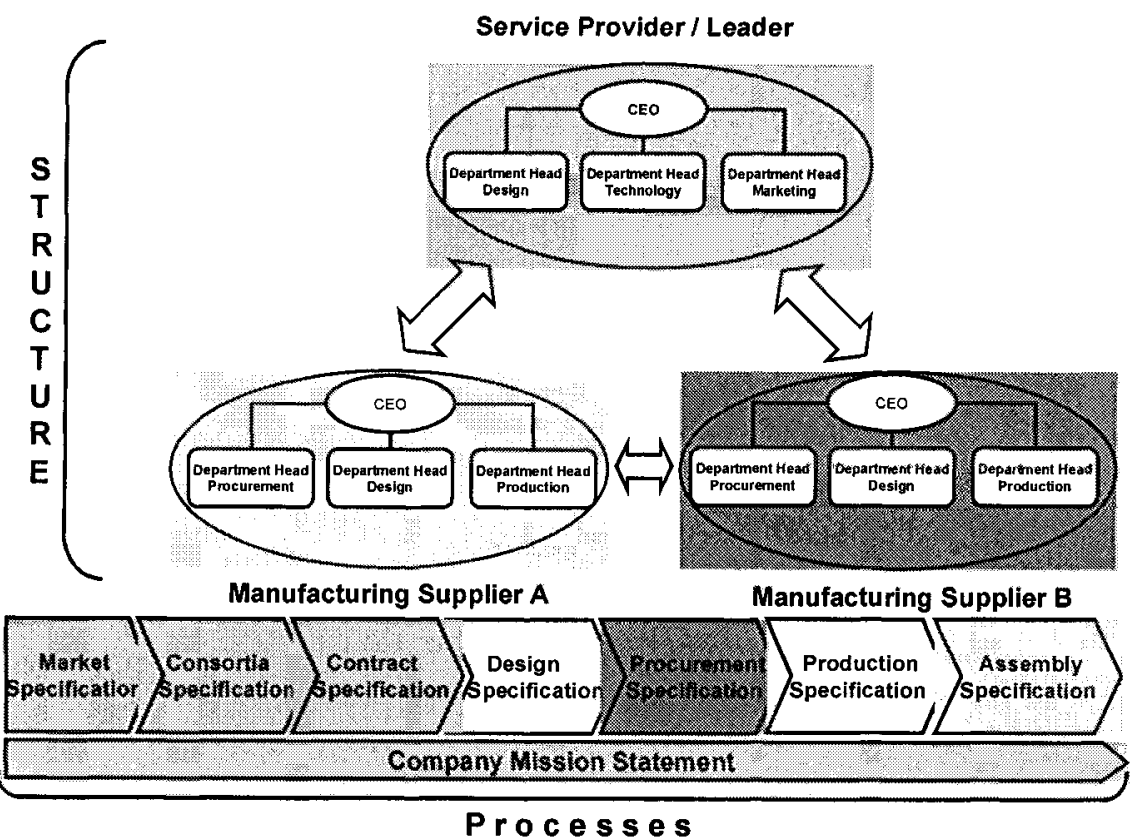

Figure 4. Game structure and processes within level 2 
Again, necessary information will be distributed unequally, the partners have to cooperate to enable constant flow of information that will then lead to a constant flow of (virtual) material and parts. To simulate interorganisational collaboration realistically, organisational boundaries like space, time, diversity, structure and distribution of knowledge and results will be addressed as well. To simulate physical distance, the arrangement of physical meetings is much more expensive. As the simulated companies are located in different time zones, synchronous communication is limited to certain time phases. Due to their different natures, the companies of course maintain different cultures that will be simulated by providing different mission statements to the particular company members. In order to simulate the structural boundary, each company will have a different "IT standard". At the beginning, data flow between the companies will be disturbed /distorted. The players will have communicate / to collaborate in order to identify the lack of interoperability as the source of problems to then agree on a common standards. During the production process, the mentioned essential knowledge concerning information processing will be distributed unequally again. The game characteristics of level 2 are summarized in Table 2 .

\section{OUTLOOK}

We have created a web based group simulation game focussing the learner's experience of company collaboration as well as organisational and interorganisational learning processes and challenges. Therefore, we have combined a gaming approach used in the simulation game COSIGA with identified processes and challenges in (inter)organisational learning. The game is currently being evaluated and validated. Furthermore, it is planned to develop an adjustable game that is able to simulate different kinds of vertical and horizontal collaborations. An accordant system architecture is in development. Additionally, modern wireless technologies will be integrated to enable an easy implementation in working and learning environments and to realistically present of future ubiquitous learning environments for engineers.

\section{ACKNOWLEDGEMENTS}

The authors wish to acknowledge, that this work has been partly funded by the European Commission though the IST Project GEM (Global Education in Manufacturing; No. IST-2001-32059). 
Table 2. Game characteristics in level 2

\begin{tabular}{|c|c|c|}
\hline Game Characteristics & Intended Effect & $\begin{array}{c}\text { Simulated Process I } \\
\text { Challenge }\end{array}$ \\
\hline \multirow[t]{2}{*}{$\begin{array}{l}\text { Unequally distributed } \\
\text { information }\end{array}$} & \multirow{2}{*}{$\begin{array}{l}\text { Increased intercom- } \\
\text { pany communication to } \\
\text { practice knowledge } \\
\text { exchange / perspective } \\
\text { taking }\end{array}$} & $\begin{array}{l}\text { Boundary of distributed } \\
\text { information }\end{array}$ \\
\hline & & $\begin{array}{l}\text { Interorganisational level } \\
\text { learning }\end{array}$ \\
\hline \multirow[t]{2}{*}{$\begin{array}{l}\text { Distributed consortium } \\
\text { responsibilities }\end{array}$} & \multirow{2}{*}{$\begin{array}{l}\text { Increased intercom- } \\
\text { pany communication to } \\
\text { practice knowledge } \\
\text { exchange /perspective } \\
\text { taking }\end{array}$} & $\begin{array}{l}\text { Interorganisational level } \\
\text { learning }\end{array}$ \\
\hline & & $\begin{array}{l}\text { Boundary of distributed } \\
\text { information \& results }\end{array}$ \\
\hline $\begin{array}{l}\text { Intercompany IT inter- } \\
\text { operability }\end{array}$ & $\begin{array}{l}\text { Practice Perspective } \\
\text { taking to identify the } \\
\text { problem, solve the } \\
\text { problem by intense } \\
\text { communication and } \\
\text { collaboration }\end{array}$ & Structural diversity \\
\hline Limited communication & $\begin{array}{l}\text { Experience communi- } \\
\text { cation \& cooperation } \\
\text { under time pressure, } \\
\text { find strategies how to } \\
\text { cope with it }\end{array}$ & Boundary of time \\
\hline $\begin{array}{l}\text { Limited physical meet- } \\
\text { ings }\end{array}$ & $\begin{array}{l}\text { Experience geographi- } \\
\text { cal distribution, Identifi- } \\
\text { cation of balance } \\
\text { between physical } \\
\text { meetings and usual } \\
\text { communication }\end{array}$ & Boundary of space \\
\hline $\begin{array}{l}\text { Each company } \\
\text { receives different } \\
\text { mission statements }\end{array}$ & $\begin{array}{l}\text { Experience inter- } \\
\text { organisational negotia- } \\
\text { tion processes, find a } \\
\text { common goal by com- } \\
\text { promising }\end{array}$ & Boundary of diversity \\
\hline $\begin{array}{l}\text { Extra task for idle } \\
\text { departments }\end{array}$ & $\begin{array}{l}\text { Identification and } \\
\text { application of strate- } \\
\text { gies how to overcome } \\
\text { such a challenge }\end{array}$ & Group level learning \\
\hline
\end{tabular}




\section{REFERENCES}

ADELSBERGER, H.; BLICK, M.; HANKE, T.:

Einführung und Etablierung einer Kultur des Wissensteilens in Organisationen.

In: Virtuelle Organisationen und Neue Medien 2002.

Eds.: ENGELIEN, M.; HOHMANN, J.

Köln: Joseph Eul Verlag, 2002. pp. 529-552

BARSON, R.; FOSTER, G.; STRUCK, T.; RATCHEV, S., PAWAR, K.; WEBER, F.; WUNRAM, M.:

Inter- and Intra-Organisational Barriers to Sharing Knowledge in the Extended Supply-

Chain.

In: E-business - Key Issues, Applications, Technologies.

Eds.: STANFORD-SMITH, B.; KIDD, P. T.

Amsterdam et al.: IOS Press, 2000, pp. 367-373.

BOSCH-SIJTSEMA, P.:

Knowledge development in a Virtual organisation: an Information Processing Perspective.

Lund: University, dissertation, 2001.

GOFFIN, K.; MITCHELL, R.:

Teaching Innovation and New Product Development using the "City Car" Simulation.

In: Proceedings of the 13th Annual Meeting of the Production and Operations

Management Society.

Miami, FL: Production and Operations Management Society (POMS), 2002.

LARSSON, R.; BENGTSSON, L.; HENRIKSSON, K.; SPARKS, J.: The Interorganizational Learning Dilemma: Collective Knowledge Development in Strategic Alliances. In: Special issue: Managing Partnerships and Strategic Alliances, in Organization Science Vol. 9 1998, pp: 285-306

MULHOLLAND, P.; DOMINGUE, J.; ZDRAHAL, Z.; HATALA, M.:

Organisational Learning: An Overview of the Enrich Approach.

In: Journal of Information Services and Use,

Amsterdam, 20(2000)1, pp. 9-23.

NONAKA, I.:

A dynamic Theory of Organizational Knowledge Creation.

In: Organization Science,

Linthicum, MD, 5(1994)1, pp. 14-37.

PAWAR, K.S.; THOBEN, K-D.; OEHLMANN, R.:

Developing concurrent engineering conceptual model and knowledge platform.

In: Proceedings of the second conference on Concurrent Engineering, Research and

Application (CERA).

Washington, DC: CERA, 1995, pp. 487-497.

RIEDEL, J. C. K. H.; PAWAR, K. S.; BARSON, R.:

Academic and Industrial User Needs for a Concurrent Engineering Simulation Game.

In: Concurrent Engineering - Research and Applications,

Thousand Oaks, CA, 9(2001)3, S. 223.

SHOSTAK, I;; ANJEWIERDEN, A.; DE HOOG, R.:

Modelling and Simulating Process-oriented Knowledge Management.

In: Proceedings of the 3rd European Conference on Knowledge Management (ECKM).

Dublin: Management Centre International Limited, 2002, pp. 634-648. 
SUMNER, T.; DOMINGUE, J.; ZDRAHAL, Z.; MILLICAN, A.; MURRAY, J.:

Moving from On-the-Job Training towards Organisational Learning.

In: Proceedings of the 12th Banff Knowledge Acquisition Workshop.

Banff, Alberta: University of Calgary, 1999.

WINDHOFF, G.:

Planspiele für die verteilte Produktion. Entwicklung und Einsatz von Trainingsmodulen

für das aktive Erleben charakteristischer Arbeitssituationen in arbeitsteiligen, verteilten

Produktionssystemen auf Basis der Planspielmethodik.

Bremen: University, dissertation, 2001. 